Vol. 3: 01-05, May 2017

ISSN: 2392-4535 (Print), 2392-4543 (Online)

DOI: http://dx.doi.org/10.3126/jnarc.v3i1.17268

\title{
Feeding Response of Tree Fodder Bhimal (Grewia optiva) on Growth Performance of Castrated Male Goats
}

\author{
Luma Nidhi Pandey ${ }^{1 @}$, Megh Raj Tiwari ${ }^{1}$, Bishnu Bahadur KC ${ }^{2}$, Niraj Baskota ${ }^{3}$ and Jagan Nath Banjade ${ }^{4}$ \\ ${ }^{1}$ Animal Nutrition Division, Khumaltar, Lalitpur; @ : pandey luma@yahoo.com; MKT <tiwari65@yahoo.com> \\ ${ }^{2}$ Goat Research Centre, Bandipur, Tanahun; <kcbishnu2071@gmail.com> \\ ${ }^{3}$ Swine and Avian Research Program, Khumaltar, Lalitpur; <neerajbaskota@gmail.com> \\ ${ }^{4}$ Regional Agricultural Research Station, Khajura, Banke; <banjadej@gmail.com>
}

Received October 2016, Revised January 2017, Accepted April 2017, Published May 2017

Scientific Editors: Tek B. Gurung, Bal K. Joshi

Copyright @2017 NARC. Permits unrestricted use, distribution and reproduction in any medium provided the original work is properly cited

\begin{abstract}
Bhimal (Grewia optiva) is a fodder tree mostly found in mid hills of mid and far western region of Nepal. Bhimalcould constitutes one of the main livestock green fodders, especially for goats when fresh green fodder become limited during the winter dry season. However, the feeding value of Bhimalleaveson growth performance of castrated goats probably has not been evaluated so far. Therefore, an experiment was conducted to evaluate theeffect of Bhimalleaves feeding ongrowth performance of castrated male goatsfor 90 days.Altogether 16 growing castrated male goats of same breed, age and body weight were selected and equally divided into four treatments T1, T2, T3 and T4 with four replications by using Completely Randomized Design (CRD). Fourtypesof experimental diets wereprepared having various levels (0 to 100\%) of Bhimalleaves as fodder. Experimental animals of Treatment 1 were fed with seasonal fodder $+100 \mathrm{~g}$ concentrate mixture, Treatment 2 with $100 \%$ Bhimal fodder +100 g concentrate mixture, Treatment 3 with $75 \%$ Bhimal fodder $+25 \%$ seasonal fodder $+100 \mathrm{~g}$ concentrate mixture, while Treatment 4 with $50 \%$ Bhimal fodder $+50 \%$ season fodder $+100 \mathrm{~g}$ concentrate mixture. All diets were fed $a d$-lib andexperimental animals had free access to drinking water. The dietsoffered and refusal was measured daily and weight change was observed fortnightly. The resultshowed that fodder intake (g/d/animal) and total dry matter intake (TDMI g/kg live weight) of goats differed significantly $(\mathrm{P}<0.01)$, but concentrate intake was not differed significantly $(\mathrm{P}<0.01)$ among treatments. The highest dry matter intake per animal /day was in Treatment $2(52.75 \mathrm{~g} / \mathrm{kg}$ live weight) followed by Treatment 4, Treatment 3 and Treatment 1 (51.7, 48.56 and $32.69 \mathrm{~g} / \mathrm{kg}$ live weight, respectively). The average daily gain in body weight was observed highest in Treatment 2 (66.66 g/d) followed by Treatment $3(31.66 \mathrm{~g} / \mathrm{d})$ and Treatment $4(30.83 \mathrm{~g})$. The growth rate was significantly $(\mathrm{P}<0.01)$ different among diet groups $(\mathrm{P}<0.05$, $\mathrm{P}<0.01$ and $\mathrm{P}<0.01$ for 60,75 and 90 days, respectively). In case of the feed conversion ratio, Treatment 2 had best ratio (8.79:1) than Treatment 1 (14.21:1), T3 (17.03:1) and Treatment 4 (18.59:1). The present response study showed thatbody weight in castrated male goatscan be increased significantly $(\mathrm{P}<0.05)$ implying that in winter season when other green forages are poorly available goat farming can be supported by Bhimalfodder tree.
\end{abstract}

Keywords: Goat, nutrition, fodder tree, Bhimal, Nepal

सारांश

मध्य र सुदुर पश्चिम नेपालमा हिउंदमा घांसहरु अभाव हुने समयमा बाखालाई खुवाउने प्रमुख डाले घांस भिमल हो । भिमल डाले घांसमा पाईने पौष्टिक तत्वहरु र यसले बाखाको शारीरिक बृद्धिमा कति योगदान गछ भन्ने बारे खासै अध्ययन भएको छैन । त्यसकारण, कृषकहरुको सहभागितामा खसी पाराएका बाखाको पाठाहरुलाई बिभिन्न मात्रामा भिमल डाले घांस खुवाई परिक्षण गरिएको थियो। यो परिक्षणमा १६ वटा पाठाहरुलाई चार समुहम तिभाजन गरि चार थरीको आहारा भिमल नभएको, १०० शतप्रतिशत भिमल, ७५ प्रतिशत भिमल र पू० प्रतिशत भिमल) ९० दिन सम्म खुवाईएको थियो। यो बाहेक प्रत्येक पाठाहरुलाई 900 ग्राम दानापनि दिईएको थियो। यो परिक्षणमा भिमलमात्र खुवाएको पाठाहरुको बृद्धि दर सबै भन्दा बढ़ (६६.६६ ग्राम प्रतिदिन) र सबै भन्दा कम भिमल नखुवाएको पाठाहरु (२Y.Y ग्राम प्रतिदिन) पाईयो। यि तथ्यहरुको विश्लेषण गर्दा बाखाको आहारामा भिमल घांसको प्रयोग गर्दा सस्तोमा मासु उत्पादन गर्न सकिने देखिन्छ। यसकारण, मध्य र सुदुर पश्चिमको मध्य पहाडमा पशु आहाराको कमी भएको बेला भिमल घांसमा आधारित आहाराको ब्यवस्था गर्न सकेमा मासुको उत्पादनमा कमी नआउने देखिन्छ,

\section{INTRODUCTION}

Goats are particularly important in subsistence livestock production system in Nepal play substantialrole in improving household economy. However, the present level of goat production is not meeting national demand of the goat meat, so thevalue of goat import from neighboring countries is high (NARC 2013). To achieve the present demands of goat meat 
production managing feed and fodder shortage in winter months (October to April) could be an important option.Fodder tree leavesis rich in protein, soluble carbohydrates, minerals and vitamins (Malik et al, 1967) constituting one of themainfood sources for ruminant.In Nepal, more than 170 species of trees, shrubs and vines used for fodder, out of thatabout 40 are traditionally cultivated by farmers (Khanal and Subba 2001).

Bhimal (Grewia optiva) is a medium sized multipurpose nutritious foddertree species growing in sub-tropical climates of north-western Himalayas, generally raised on terrace risers, fairly well distributed up to middle elevations (500-2500 masl) in India, Pakistan and Nepal (Semwal et al 2002). It is a most popular and potential trees species for use in community forestry of Doti district of western Nepal (Stewart, 1983).The Bhimal fodder is quite crucial as it provides nutritious fodderduring the lean season (Singh 1982). The Bhimalfodder contains $17.35-21 \%$ crude protein, 17-21.51\% crude fiber, 10.42-21.50 \% total ash, 4.21-6\% ether extract and 40.41-50.24\% nitrogen free extract (Shankhyn and Bhagta 2016) and do not contain tannins (Orwa et al 2009). Bhimal fodder yield is reported to be 11 ton/ha from 2-year old plants, green fodder yield from mature trees is reported to be 12-30 kg (Orwa et al 2009).

In Nepal, feeding response of Bhimal fodder on growth performance of goats especially with castrated males has rarely been evaluated. Therefore, the aim of this study was to identify the specific level of Bhimal fodder inclusion on goat ration for developing low cost feeding packages to the goats. We hypothesized that Bhimal could increase the weight gain in goats without increasing concentrate ration.

\section{MATERIALS AND METHODS}

Experimental site and animal selection and chemical analysis of feeds and fodder

This study was carried out in close participatory approach with the farmers of Dhanabang Village Development Committee ofSalyan district, Nepal. The experiments were carried out for 90 days with seven days of adjustment period (November to January 2015 and 2016). Sixteen castrated Khari male goats were purchased from local villagers. All goats were of average 5 months old with an average body weight of $13 \mathrm{~kg}$. These goats were grouped into fourtreatments by using Complete Randomized Design (CRD) having four in each as replicates. They were drenched with Fenbendazole @ $5 \mathrm{mg} / \mathrm{kg}$ body weight against internal parasites before experiment. Experimental animals were kept in wooden cage individually. Collected sample of fodders (Bhimal, Rahej, Katus, Ganaune) and concentrate mixture was sent to Animal Nutrition Division, Khumaltar for DM and CP analysis. The dry matter was determined by oven drying at $100 \mathrm{C}^{0}$ for 24 hours. CP of the samples was determined using the Kjeldalh method (AOAC 1980). Concentrate mixture of $16 \%$ crude protein content for experimental animals was procured from Karnali Feed Industry, Manikapur, Banke, Nepal.

Experimental diets, feeding regime, observation recording and data analysis

The dry matter requirement of goats was calculated based on $4 \mathrm{~kg}$ per $100 \mathrm{~kg}$ body weight. The diet was composed from fodder Bhimal (DM 36.28\%), Concentrate mixture (DM 86\%) and seasonal fodder ie, locally called as Rahej (DM 56.31\%), Katus (DM 47.94\%) and Ganaune (DM 45.27\%). Following diets were formulated to the experimental animals (Table 1).

Table 1. Experimental diet composition for feeding experiment to castrated male goat

\begin{tabular}{ll}
\hline Treatment & Experimental diets \\
\hline T 1 & Seasonal fodder adlib +100 g concentrate mixture \\
T 2 & $100 \%$ Bhimal +100 g concentrate mixture \\
T 3 & $75 \%$ Bhimal $+25 \%$ seasonal fodder +100 g concentrate mixture \\
T 4 & $50 \%$ Bhimal $+50 \%$ seasonal fodder +100 g concentrate mixture \\
\hline
\end{tabular}

Concentrate mixture was provided to the experimental animals individually once a day in the morning in plastic vessel, whereas fodder was provided twice a day in group. Quantity of concentrate feed and fodder given daily to the animals was weighed daily and refusal was weighed in next morning. Experimental animal had free access to drinking water. The trial period covered 90 days after the 7-day adaptation period. Total goat feed was recorded daily throughout the experimental period. The weight gain of the individual animals was measured every two weeks before feeding. Data of feed intake and body weight gain were analyzed by One-way ANOVA test for every measurement using computer statistical package Minitab 2003, versions 13.20. 


\section{RESULTS}

\section{Nutrient contents of feed and fodder}

Four types of locally available fodder tree including Bhimal and concentrate mixture feed were used to formulate diets for experimental goat (Table 2).

Chemical analysis revealed that Rahej had highest DM content (56.31\%) whereas, Bhimal had (36.28\%). In case of CP content, Bhimal was superior (20.7\%) followed by Rahej (13.8\%) and Ganaune (12.6Concentrate mixture had $86 \%$ DM and $16.4 \% \mathrm{CP}$.

Table 2. Dry matter (DM) and Crude Protein (CP) levels (in \%) in different fodder and concentrate feed offered to castrated experimental goats

\begin{tabular}{lcc}
\hline Name of feedstuff & \multicolumn{3}{c}{ Nutrient contents, \% } \\
& DM & CP \\
\hline Bhimal & 36.28 & 20.7 \\
Rahej & 56.31 & 13.8 \\
Ganaune & 45.27 & 12.6 \\
Katus & 47.94 & 11.99 \\
Concentrate & 86 & 16.4 \\
\hline
\end{tabular}

\section{Feed intake}

Bhimal fodder intake $\mathrm{g} / \mathrm{day}$, seasonal fodder intake g/day and total dry matter intakes (TDMI $\mathrm{g} / \mathrm{kg}$ live weight) of goats differed $(\mathrm{P}<0.01)$ among treatment groups, but concentrate feed intake were not different significantly (Table 3$)$. The highest feed intake was in Treatment $1(97.1 \mathrm{~g} / \mathrm{d})$ followed by Treatment 3 and Treatment $2(96.92$ and $95.49 \mathrm{~g} / \mathrm{d}$, respectively) which was not significant $(\mathrm{P}<0.001)$ among diet groups, whereas fodder intake was highly significant $(\mathrm{P}<0.001)$ among diet groups. The highest dry matter intake was found in Treatment $2(52.75 \mathrm{~g} / \mathrm{kg}$ live weight) followed by Treatment 4 , Treatment 3 and Treatment 1 (51.7, 48.56 and $32.69 \mathrm{~g} / \mathrm{kg}$ live weight, respectively).

Table 3. Feed intake levels (in gram per day) of castrated goats during the experimental test

\begin{tabular}{lccccc}
\hline Parameter & Treatment 1 & Treatment 2 & Treatment 3 & Treatment 4 & P \\
\hline Concentrate mixture intake, g/d & $97.10 \pm 13.3$ & $95.49 \pm 16.9$ & $96.92 \pm 15.1$ & $95.04 \pm 18.3$ & 0.225 \\
Bhimal intake, g/d & 0 & $1396.9 \pm 30.1$ & $904.8 \pm 21.9$ & $641.7 \pm 19.9$ & 0.00 \\
Seasonal fodder, g/d & $864.8 \pm 21.6$ & 0 & $261.4 \pm 18.5$ & $527.2 \pm 12.3$ & 0.00 \\
Total dry matter intake, g/ kg live wt. & 32.69 & 52.75 & 48.56 & 51.7 & 0.00 \\
\hline
\end{tabular}

\section{Body weight gain}

Body weight gain $(\mathrm{kg})$, weight gain per day $(\mathrm{g} / \mathrm{d})$ and feed conversion ratio (FCR) of experimental goats on different level of Bhimal inclusion are presented in Table 4.

Table 4. Body weight gain (in Kilogram) in experimental castrated males and Food Conversion Rate (FCR) in different treatments (mean \pm SD)

\begin{tabular}{lcccc}
\hline Parameter & Treatment 1 & Treatment 2 & Treatment 3 & Treatment 4 \\
\hline Initial body weight, kg & $11.6 \pm 0.83$ & $13.33 \pm 1.47$ & $13.15 \pm 1.23$ & $13.48 \pm 0.87$ \\
Final Body weight, kg & $13.9 \pm 1.47$ & $19.33 \pm 2.02$ & $16 \pm 1.61$ & $16.25 \pm 0.50$ \\
Total weight gain, kg & $2.3 \pm 2.3$ & $6 \pm 1.2$ & $2.85 \pm 1.9$ & $2.77 \pm 3.1$ \\
Initial metabolic body weight, kg & 6.28 & 6.97 & 6.90 & 7.03 \\
Final metabolic body weight, kg & 7.19 & 9.21 & 8 & 8.09 \\
Total weight gain, kg & 2.3 & 6.0 & 2.85 & 2.78 \\
Average daily gain, g & 25.55 & 66.66 & 31.66 & 30.83 \\
Feed conversion ratio (FCR), kg & $14.21: 1$ & $8.79: 1$ & $17.03: 1$ & $18.59: 1$ \\
\hline
\end{tabular}


In the beginning of the experiment initial weight was almost similar for Treatment 2, Treatment 3 and Treatment $4(13 \mathrm{~kg})$ and in Treatment $1(11 \mathrm{~kg})$ which was not significant $(\mathrm{P}>0.05)$ among diet groups. By the end of experiment (after 90 days) total weight gain from Treatment 2 was higher $(6 \mathrm{~kg})$ followed by Treatment $3(2.85 \mathrm{~kg})$ and Treatment $4(2.77 \mathrm{~kg})$. The average daily gain was observed highest in Treatment $2(66.66 \mathrm{~g})$ followed by Treatment $3(31.66 \mathrm{~g})$ and T4 $(30.83 \mathrm{~g})$. At the beginning up to 45 days of experiment growth rate was not differed significantly $(\mathrm{P}>0.05)$ among the diet groups, but from 60 days onward it became significant $(\mathrm{P}<0.05, \mathrm{P}<0.01$ and $\mathrm{P}<0.01)$ for 60,75 and 90 days, respectively among different diet groups. Similarly, feed conversion (DMI: g/kg live weight gain) ratio was highest in Treatment 2 (8.79:1) followed by Treatment 3 (17.03:1) and Treatment 1 (14.21:1).

\section{DISCUSSION}

Crude protein (CP) content is most important criterion for judging feed and fodder quality. Based on CP content fodder tree, shrub and climber can be classified as high ( $>20 \%)$, moderate $(10.01$ to $19.99 \%)$ and low $(<10 \%)$ class (Upreti and Shrestha 2006). In general, the crude protein is highest in young leaves and in winter leaves, but low during rainy season. The CP content in Bhimal leafy fodder in our analysis was $(20.7 \%)$ (Table 2). This finding was similar to data given by Shankyan and Bhagta (2016) in fodder analysis report showing CP ranging from $17.35-20.99 \%$. However, the CP ranges of other seasonal fodders used in present experiments were moderate ranging from 10.99 to $13.8 \%$ in Rahej, Ganauneand Katusfodder (Table 2). The Bhimal leaves were almost as nutritious as leguminous fodder (Singh 1982) with high digestibility, good vitamin and mineral content for enhancing microbial growth and digestion of cellulosic biomass in rumen (Orwa et al 2009).

In general, intake of food and other resources in relation to growthin organisms are associated with each other; a change in one of the traits will result in a change in the other.In present experiments the inclusion of Bhimal fodder in the goat diets significantly $(\mathrm{P}<0.01)$ effected fodder intake and total dry matter intake (Table 2 and 3). Phengsavanh and Ladin (2003) also showed similar results of higher feed intake rate afterinclusion of Bhimal fodder. This might have been due to higher CP level in Bhimalcreating better rumen environment for digestion of food. Sharma et al (1996)revealed that the leaves of Bhimal were readily eaten and average intake of DM was $48.7 \mathrm{~g} / \mathrm{kg}$ live weight in November and January as have been shown with only Bhimal fodder treatment in T2 (52.75 g/kg live weight, Table 3). Moreover, Singh and Gupta (2008) reported that sheep and goats had relatively higher feed intake, nutrients digestibility and total volatile fatty acid (TVFA) production on Bhimal and Cenchrusciliaris mix diet than on Leucaena and Cenchrusciliaris mix diet where goat had higher CP digestibility than sheep on Bhimal and Cenchrusciliaris mix diet.

Overall growth of goats was significantly $(\mathrm{P}>0.05)$ different among dietsbut there was similar weight change pattern of goats up to 45days of experiment (Table 4). From 60 days onward, it became significantly different among diet groups $(\mathrm{P}<0.05$, $\mathrm{P}<0.01$ and $\mathrm{P}<0.01$ for 60,75 and 90 days, respectively). Total gain and average daily gain were observed highest (66.66 $\mathrm{g} / \mathrm{d}$ ) in only Bhimal fodder fed Treatment 2 and lowest $(25.55 \mathrm{~g} / \mathrm{d})$ in without Bhimal diet (Treatment 1). Similar result $(66.67 \mathrm{~g} / \mathrm{d})$ of Bhimal feeding was observed in a study performed in winter season in Punjab (Sharma et al, 1996). Our results also showed the best FCR was in Treatment 2 than other Treatments. All these results indicate that the Bhimal fodder is superior in nutrients content and digestibility than other seasonal fodders. Singh et al (1989) reported that Grewia optiva had over $70 \%$ potential DM digestibility and effective degradability was $56.7 \%$. The digestion characteristics of the tree leaves of G. optiva revealed to be superior energy sources for ruminants (Singh et al 1989). A comprehensive study revealed that out of 13 species of forest tree leaves of Morusalba, Ehretialeavis, Grewia and Leucaenawere highly nutritious and showed great potential as alternate feed resources (Bakshi and Wadhwa, 2004). Similarly, in-vivo studies revealed that the leaves of high CP content fodder, Meliaazedarach, Morusalba and Leucaenaleucocephala supplemented with mineral mixture and common salt could be fed as complete feed to goat bucks (Bakshi and Wadhwa 2007).

Other similar results are reported on feeding of high CP feed. As Anbarasu et al (2004) reported that leaf flour mixture containing Leucaenaleucocephala, Morusalba and Tectonagrandis could be supplemented with wheat straw-based diets for goats without any adverse effect on the utilization of voluntary intake of nutrients. Cheemaet et al (2011) revealed that selected tree leaves due to high $\mathrm{CP}$, shorter delay time and faster digestive grade could be compatible with concentrate feedings. 


\section{CONCLUSION}

Bhimal is superior in crude protein content; readily eaten by goats to increase dry matter intakethan other various fodder trees found in mid and far western mid hills of Nepal. Bhimal can increase the weight gain in goats without increasing concentrate ration that reduce the costs in goat production. Therefore, Bhimal based feeding packages for goat production is suitable, sustainable and beneficial to the farmers of mid and far western hill region of Nepal.

\section{ACKNOWLEDGEMENT}

The authors are grateful to Nepal Agricultural Research Council for financial support of this study. Goat raisers of Dhanabang VDC of Salyan district are highly acknowledged for their support and cooperation. Similarly, authors would like to express their gratitude to the team of District Livestock Services Office, Salyan.

\section{REFERENCES}

Anbarasu, C., N. Dutta, K. Sharma and M. Rawat. 2004. Response of goats to partial replacement of dietary protein by a leaf meal mixture containing Leucaena leucocephala, Morus alba and Tectona grandis. Small Ruminant Research 51(1): 4756.

AOAC. 1980. Association of official Analysis Chemists. Official methods of analysis, USA.

Bakshi, M P S and M. Wadhwa. 2004. Evaluation of forest tree leaves of semi-hilly arid region as livestock feed. Asian- Australasian Journal of Animal Sciences.17: 777-83.

Bakshi, M P S and M.Wadhwa. 2007. Tree leaves as complete feed for goat bucks. Small Ruminants Research.69: 74-78.

Cheema, U. B., J. I. Sultan, A. Javaid, P. Akhtar and M. Shahid. 2011. Chemical composition, mineral profile and in situ digestion kinetics of fodder leaves of four native trees. Pak. J. Bot, 43(1): 397-404.

Khanal, R. C. and D. B. Subba. 2001. Nutritional evaluation of leaves from some major fodder trees cultivated in the hills of Nepal. Animal Feed and Science Technology 92: 17-32.

Malik, M.Y., A.A. Sheikh and W.H. Shah. 1967. Chemical composition of indigenous fodder tree leave. Pak. J. Sci., $19: 5-7$.

NARC 2012. Nepal Agricultural Research Council. The Proceedings of National Workshop on Research and Development Strategies for Goat Enterprises in Nepal (Eds. Gurung T.B., Joshi B.R., Singh U.M., Paudel K.P., Shrestha B.S., Rijal K.P. and Khanal D.R.), NARC, Kathmandu, April 2013. PP 316 page

Orwa, C, A. Mutua, R. Kindt, R. Jamnadass and A. Simons. 2009. Agroforestry Database: a tree reference and selection guide version 4.0 (http://www.worldagroforestry.org/af/treedb/).

Phonepaseuth, P. and I. Ledin. 2003. Effect of Stylo 184 (Stylosanthes guianensis CIAT 184) and Gamba grass (Andropogon gayanus cv. Kent) in diets for growing goats; Livestock Research for Rural Development 15 (10). Retrieved November 22, 2006, from http://www.cipav.org.co/lrrd/lrrd15/10/seut1510.htm

Sankhyan, H P and S. Bhagta. 2016. Fodder quality analysis of open pollinated seedling seed orchard of Grewiaoptiva Drommond. The Bio Scan. 11(2): 709-713.

Semwal, R. L., R. K. Maikhuri, K. S. Rao, K. Singh and K. G. Saxena. 2002.Crop productivity under differently lopped canopies of multipurpose trees in Central Himalaya, India.Agroforestry Systems. 56: 57-62.

Sharma, D. D., S. S. Negi and G. S. Sidhu. 1996. Chemical composition and nutritive value of biul (Grewia oppositifolia Roxb.) tree leaves. Journal of Research-Punjab Agricultural University. 3: 178-185.

Singh, B., H.P.S. Makkar and S.S. Negi. 1989. Rate and Extent of Digestion and Potentially Digestible Dry Matter and Cell Wall of Various Tree LeavesJournal of Dairy Science, 72 (12): 3233-3239.

Singh, RV. 1982. Fodder Trees of India, 663 pp. Oxford and IBH Publ. Co., New Delhi.

Singh,S. and A Gupta. 2008. Feed intake, eating pattern, nutrient digestibility and rumen metabolites in sheep and goat fed gross tree leaves diets. The Indian Journal of Animal Sciences. 78, N 6.

Upreti, C. R. and B.K.Shrestha. 2006. Nutrient Contents Feeds and Fodder in Nepal. Animal Nutrition Division, NARC, Khumaltar, Nepal.ISBN 99933-703-6-3. First Edition; Page 1-3. 